\title{
An Ideal World in the Medieval SUFI Literature of Siberian Tatars
}

\author{
Lyailya Gelsovna Khusnutdinova1
}

\author{
Svetlana Dmitrievna Galiullina1 \\ Oksana Mikhailovna Ivanova1 \\ Larisa Mikhailovna Bilalova²
}

Flera Sagitovna Sayfulina ${ }^{3}$

1 Ufa State University of Economics and Service, 450078, 145 Chernyshevskiy str., Ufa, Bashkortostan ${ }^{2}$ Branch of Bashkir State University in Birsk, 452453, 10 International str., Birsk, Bashkortostan

${ }^{3}$ Kazan Federal University

E-mail: radogost2000@mail.ru

\section{Doi:10.5901/mjss.2015.v6n3s4p207}

\begin{abstract}
The author researches the problem of manuscript Sufi literature, which has almost dropped off scientists' radar. This article is based on the personal author's materials, where she has found out and settled manuscript evidences of Sufi people, which hadn't been documented before. The author defines the problem of the ethnic and confessional cultures' interconnection in the context of the embedded stereotypes. These stereotypes motivated the Sufi people to move towards to extremely unfavorable for a south person Siberian and North conditions. Analyzing the works of such poets as Ikany, Huvaydo, Amdamy, some fairytales and dastans (recorded by V.V. Radulov), the author explores mythological synopsis as the basis of branched system of mythological plots in the Sufi Siberian Tatar literature on the ground of dhikr. The author analyzes the inner worldview transformation of Sufi lkany, who came to the Siberian bogs and forests from Arabian sands to prove perishable nature of all the material in front of the spirit.
\end{abstract}

Keywords: Sufism, dhikr, Islam, Siberian Tatars, Arabs, interconnection, manuscripts.

\section{Introduction}

Being esthetically and educationally valuable, the medieval literary monuments arouse a certain interest in the terms of both science and history. Explanation, interpretation and annotation of ancient and medieval written monuments are one of the main approaches to the work primary analysis, that helps to understand and reproduce the central idea, stated for a modern reader by the writer in his understanding. By XVIII - XIX century the Tobolsk province had become the cultural and educational center, where scientists and educators from Siberia, Volga region and Middle Asia were united. It happened because this province is the crossover point of historically related Turkic literature and cultures: Tatar, Uigur, Kazakh and etc. (Karabulatova, Koyche \& Gultyaev, 2013; Yusupov \& Karabulatova, 2014; Zamaletdinov et al, 2014; Karabulatova et al, 2014 \& Sayfulina et al, 2013). In the XIX century in this region there were the libraries, where were kept numerous ancient editions, brought from Bukhara, Saudi Arabia and Turkey and other Muslim countries. This is the result of interaction between them. (Sayfulina et al, 2013 \& Karabulatova and Sayfulina, 2015). In accordance with the research task, we appeal to some known sources, which are the masterpieces of the Sufi poets, whose lives are anyhow connected with Siberia. Analysis of Sufi poets' works, written in Arabic graphics mostly in handwritten form, shows that Karagayskye Jurts of Tobolsk region were "the stronghold of Sufism", "the center of Muslim region", some kind of "the residence of Siberian-Tatar or Siberian Bukhar Hadji" anyhow connected with the congregation of Naqshbandi (Sayfulina et al, 2013, p. 493). The Sufi philosophy of Naqshbandi is based on classical theology "wahdat ash-shuhud", stated by Ahmad al-Farūqī al-Sirhindī (1564-1624), one of its spiritual founder, as "Allah is the Creator of all things" (Sayfulina et al, 2013).

For the moment more than 350 of holy places have been found and described inside the territory of Siberia. For example, Astana is the burial place of Naqshbandi sheikhs. In the culture if Siberian Tatars "Astana" is the aspect of the local saints cult, that isn't recognized as Koranic, but is an important element of so called folk Islam, which had different 
archaic believes and ceremonies as its part (Karabulatova \& Sayfulina, 2015, p. 303). Renaming of Kazakhstan's capital, that nowadays also has this name Astana, strengthened the sacral layer in believes of Astana in Turkic area (Karabulatova et al, 2014, p. 15). The word Astana has Arabic origin, it means "the door's threshold", "the doorway to the palace" (Karabulatova, Ermakova \& Chiganova, 2014, p. 16). But the whole layer of Sufi culture is closely intertwined with the local folk believes, that let the scientist to talk about mutational character in the ethno-lingual personality of the Siberian inhabitant (Karabulatova, 2013, p. 794). In the first place we are interested in the identification of the authors of the medieval Sufi masterpieces, found in the Siberian area. Further we raise the question of the transformation in the authors' lingvomental individual worldview under the influence between languages and cultures.

\section{Materials and Methods}

More than 2200 books and rare manuscripts are kept in the funds of Embaevskiy madrasah (Tyumen region) library, founded by a merchant and a patron Nigmatulla Hadji. Created in Siberia in different years, written literature sources are kept up to the present. The analysis of these sources in the context of Tatar literature's history development has given an opportunity to build a definite picture of Tatar literature's formation and development in Tyumen region and to follow the common patterns of its development. (Sayfulina et al, 2013). The discovered manuscript sources were written in the language of Siberian Tatars in the form of Arabian graphics. We can observe a definite succession with Siberian genealogy (sachere| shazhere), written with Arabian graphics on the fabricated calfskin, and then on the paper first in Roman letters, and then in Cyrillic script.

In the "Bakyrgan book", made up of 143 lyrico-philosophical and lyrico-epic masterpieces, there are the poems of Ikany (from 90 till 108). From 1847 this anthology has been published in Kazan several times. But these masterpieces are underexamined and not analyzed in literature context. This book wasn't republished in the Soviet Period. Only In 2000 the "Bakyrgan book" went out into the world. The mythological plots of the sacral reign are aligned with the plots of fairytales and dastans written by V.V. Radlov (e.g. "The Golden Hunter"| Tsontay Mergen") (Sayfulina \& Karabulatova, 2014).

\section{Results}

As noted in the works of many theorists of literature, the notion that is put in the word Dhikr is one of most fundamental and significant idea in the Sufi literature. In the research papers this term is interpreted as a Sufi prayer, as appeal to the Most High.

One of the central ideas in the Ikany's works is connected with the Sufi philosophy "Dhikr". Based upon the poems, Ikany realizes "Dhikr" not only as religious and ritual action, but also as an requirement of person's affection. In poet's opinion, the "Dhikr" is an appeal to the Supreme Being, that helps to cleanse the soul for perception of absolute truth. Sometimes in Ikany's poems there is a Turkic variant «yad kylu», that is used instead of the word "Dhikr" and means to keep in mind, to remember. But the meaning of appealing to the Supreme Being of Sufi people is not "to keep him simply in mind". Ikany affirms that the Supreme Being must be understood and realized not only in mind, but also in soul.

As Ikany wrote repeatedly, "to remember about the Supreme Being and carry his image in the soul" is not only a religious ritual, but also a certain emotional state of a believer in everyday objective reality. In his poems lkany often reminds that under communication with spiritual Master we shouldn't "stay asleep", it's necessary to get "batyyn" so called secret knowledge, which is connected with the Absolute Truth, to become his "friend" and to follow him. The poet also writes about "zahir", that is an "evident side of knowledge", mentioning that this side, being not connected with the true facts of the matter, is something temporary, but not eternal. The world around the person, an objective reality for the Sufi are the temporary state of affairs, that always and everywhere betrays a person, taking a soul away from the real knowledge. Affirming the ability to get the Truth, in his poems Ikany mentions "dargah" "a door to the Truth" and writes that "a greedy person is not respected at the door to the Truth". The poet often refers to "Ahirät" that means "the Other World", realized by Ikany as "the world of absolute Truth". With the transition to "the Other world" a believer's soul reaches immortality, constant happiness and paradise. Thereby a thirsting for the Truth person, as says Ikany, must save the Truth in his soul, receive a secret knowledge and make the good deeds.

Ikany writes in his poem devoted to the "Zakir", that means praying to the power of the Supreme Being:

Munis itkel yadyny küngleng edä dayimä,

Kalmay sän, änäs, härgiz näphse-shäitanyn belän.

Make a friend to the Supreme Being's soul -

Then wouldn't you be a person left with your passion, with Satan. 
Hereby the poet affirms that if you always remember about the Supreme Being and make the refuge of the Truth from your soul, your passions and avidity won't torment you. As the Sufis thought avidity, an insatiability and the passions are the features that present in each person and are generated by the Devil.

If these vices get the upper hand, there is no doubt that you become a Satan's servant. But it's possible to make a mash on devil feelings, if to believe with all your soul in Supreme Allah. Learning the eternal Truth person can't be avid, greedy, because material world and objective reality are a temporary refuge for him. Ikany writes that avidity and greed break the belief, that's

why a believer must be always "full of tears", remembering about the Supreme Being. A person

"giryan", in other words "full of tears", doesn't spend time entertaining, this person always thinks, imagines. The Sufis consider inactl ivity and laziness as the most disreputable personal features. Ikany motivates a reader to acquire the knowledge, to experience the world:

\section{Mägarifät hasil kyl vä bul ähle-gyyrfan hiyledin, Ciyde kylgy üzengä galämne gyyrfanyng belän. Educate and be among those who is cognizing, Through the Sufi doctrine to experience the Universe.}

As Ikany marks the cognition is reached in order to spread enlightenment. The poet continues that referring to oneself, telling one's name, "a person is obliged to stay in tears and in grief day and night, because only then he will be able to find the Supreme Being. It's obvious that this is the author's understanding of the way how to reach the Truth. It's typical for the Sufi doctrine about the Absolute Truth. The poet states that a person cannot be ignorant, because only his belief remains in the end of life journey, that is the Truth reached in the course of a lifetime. Material goods, riches and everything are left on this earth, in this world, nobody can take them with them, but the Truth, firmly took the first place in the soul and wouldn't disappear, because the soul is immortal. That's why lkany calls upon for "Zakir", upon for a praying person who believes in the Supreme Being, to cognize and to bring the Truth into his soul. For a Sufi cry, tears are definite psychological condition of spiritual self-perfecting.

\section{Egalagyl u hälengä, bu däm ki forsattyr sänga, \\ Bu tereklek, bel yakyn, äsir-ganimätter sänga. \\ You are given the chance to moan your condition, \\ This life, learn it by heart, is your riches.}

In such manner the author asserts that tears are given to a person for purification of his soul. Ikany supposes that "an exhausted soul in the body is only a guest for five days", where "five days" are conventional metaphor, vivid expression, but not a qualitative importance.

Researching lkany's works, it's necessary to put attention that an appeal to the

Supreme Being as Tangra is used rather often as well as in the Turko-Tatar poetry and in the modern speech of Siberian Tatars. The Sufis thought that the name of the Supreme Being is unknown for ordinary people, and Allah, Tangere and etc. are simply the signs of the Most High. One of Ikany's poems, reflecting the author's thinking about human soul, is about an opportunity to purify it, begins with these words: "Egalagyl u hälengä...". In the poems " I bihayr", "Uீlemneng ilchese", "Uீlem kilde" and etc. Ikany reminds the idea of the Sufi crying.

The lkany's poem "Bifadyr oshbu dönya" is devoted to the sense of life on this Earth. As the poet thinks, a person cannot rely on this world because, after all, this world can give only death. If even a few Universes are the person's "slaves", it'll make no difference, because death brings end for everything. Only belief can help a person in this life, and this believe cannot do without "Zhikr". If there is no name of the Supreme Being in the person's soul, he is without belief.

Ikany admits that, if a person isn't burning in the flame of "love to the Supreme Being", he isn't a real person. Out of this understanding of eternal life in the Other World, the poet asks to keep the Truth, to remember always the Supreme Being, to carry his name in the soul. But at the same time in the Ikany's poetry there is an idea that the life on this Earth is also priceless and herein there is a contradictoriness of his poetry. The idea of human life's importance is touched in the poem "Gomer kadere". The poet is sure that life is priceless, but it will become senseless under ignorance, without learning the Truth. A person must commit only good things with gratitude to the Supreme Being, because on the Judgment Day, he will have to answer for all his actions.

The Sufi morals are typical for the other lkany poems, where he teaches virtuous actions, reminds of the necessity to fulfill Namaz, to read the Koran and etc. In the poem "Uyangyl" the author calls not to be an ignoramus, as if the poet refers to himself. He writes: "Gariplykta ülär irmesh Ikanyj". This poetical line has become an indirect proof for the 
researcher that the author writing these lines, was in the foreign land. It strengthens hypothesis that the poet and Sheikh Ikany are one and the same person. This masterpiece attracts attention both with the peculiarity of composition and with the content. The composition of the analyzing book is typical for Sufi literature. It consists of introduction (Bashlam), where it's also possible to find the stanzas, which can be taken to the Munadzhat part and to the numerous chapters of stories-hikayates united together by the same problem of religious instructions and edifications. The whole book is directed to the moral and religious education that gives an opportunity to attribute it to the Sufi poetry.

\section{Discussion}

We suppose that the search of an ideal world by Sufi people led them to Siberia, which has anciently been a sacral confabulated area in the world socium (Karabulatova, Fedorova \& Sayfulina, 2014). The complexity of Sufism is that there are many unwritten aspects of this doctrine. There are things that a Sufi person can see, feel and know, but can't reproduce. In this regard there are many facts which are off-screen, but they are conjectured by the addressee, leaving many opportunities to interpret on the basis of the disciple's level of training, as far as the Sufism is based on the oral transmission from the mentor to the disciple. In this case we can see a psychotherapeutic function of the Sufism, which balances between different mental states and emotional states (Edinger, 1991).

In this meaning the Sufism is a real practice where a person can acquire a psychological integrity, known as the process of individualization in analytic psychology (Edinger, 1992). The search of the sense goes through the meeting with the symbolism in religion, myth, dream and art. This process of meeting within yourself is equivalent to the revelation of God, who presents everywhere. For many centuries the Sufism was an object of careful attention from the part of west and east philosophers, philologists and historians.

F.Z. Yakhin considers Ikany to originate from the area of Siberian Tatars (Yakhin, 2006). However, the results of comparative contrastive textual analysis point to affirm that the Sheikh Ikany could be one of the sheiks, who brought the Islam to Siberia (Sayfulina et al, 2013, p. 494). Some lines of his poems, where he compares the gone word of his native culture with the acquired Siberian culture, point to this fact. And then the world is the polyvariable combination of ethnocultural codes, and its interpretation is compared to the making sense of a complicated lingvomental conundrum, where the deep archetypical images are interwoven (Sells, 2000; Edinger, 1992 \& Sayfulina \& Karabulatova, 2013).

The result of the dialog between an ego and an archetypical image of God is the experience of Sufi people that changes cardinally a person's worldview and makes possible a new and more meaningful image of a life. The Siberian Sufism studies the human involvement and development that distinguish a person himself.

\section{Conclusion}

From the end of the XVIII and the beginning of the XIX centuries orientalists from Russia, Hungary, Germany, Turkey, Poland and other countries began to take academic interest toward the literature monuments of Tatar people, created in the Middle Ages. They could decode and publish many literature texts, thanks to which there appeared an opportunity to research them more deeply. Modern textual science decides the problems of explanation and interpretation of the questions connected with ancient and medieval written artifacts' creation and authorship.

Tatar people read different books about theology, Muslim jurisprudence (figh), medicine, pedagogic, astronomy, philosophy and, of course, they read belletristic literature. Before first published Tatar books in the XIX century they used manuscript books. While expensive manuscript books were the part of rather slender and difficult handicrafts for Tatar people and for the whole Muslim East, they had wide currency. There was an enormous demand for these books. The Tatar book peddlers spread them not only among their tribesmen, but also among kindred nations such as Bashkir people, Kazakh people and etc.

Throughout many centuries the Tatar spiritual culture was the part of the Arab-Muslim civilization. Its development up to the Revolution in 1917 went with the tide of processes flown up in the Islamic East. In the history of development of the Sufi views there are many tendencies, which differ in their extreme variety. Many scientists affirm that there wasn't any united concept of Sufism in effect because of society development and different brotherhoods appearance. But all of them served a great purpose; they were united to the perfection of a person's spiritual world. The Sufis proclaimed their commitment to the Prophet's doctrine. Ceremonies and traditional believes hadn't any special importance in comparison to the Faith in Allah, which stays only "in the pure heart". The Sufis thought about the sense of the Koran poems, strictly followed the Prophet's prescriptions and Sunnas, prayed much, kept the fast, took the cult of poverty and hard work for Nammarga. The hallmark of Sufi poetry is deep analysis of the deepest personal experiences, because their highest goal is to ascent the Truth. The literature monuments of the Middle Ages witnesses about a deep penetration in the Tatar 
public conscience the ideas typical for Muslim theology and philosophy.

Publication realized with the financial support of the Government of RHF and the Republic of Bashkortostan "Ural: history, economy, culture" research project № 15-11-02004 "Place and role of regional and local authorities in the integration of migrants into the local community (in the case of the Republic of Bashkortostan, Perm Krai , Orenburg region)" and a research project № 14-11-02011 "The role of national-cultural associations in the integration of migrants into the local community in the Volga region (the Republic of Bashkortostan, Tatarstan, Samara Region)".

\section{References}

Edinger, E.F. 1991. Anatomy of Psyche: Alchemical symbolism in Psychotherapy (Reality of Psyche Series). Open Court Published Company. pp. 284.

Edinger, E.F. 1992. Ego and Archetype. Shambhala. pp. 304.

Karabulatova, I.S. 2013. The problems of linguistic modeling of new Eurasian linguistic personality in multilinguistic and mental environment (by example of onomasphere). In the: Middle-East Journal of Scientific Research 17 (6). pp. 791-795.

Karabulatova, I.S., Koyche K.K. \& Gultyaev V.N. 2013. The Dialogue of Kazakh Steppe and Russian Forest: About the Character of Turkic-Speaking Linguistic Personality on the Territory of Russian-Kazakhstani Border-Zone. In the: Middle-East Journal of Scientific Research 17 (7). pp. 853-858.

Karabulatova, I.S., Ermakova E.N. \& Chiganova G.A. 2014. Astana in Kazakhstan and Astana in Siberia as a form of national Islam of Eurasia in the linguistic-cultural aspect. In the: Terra Sebus: Acta Musei Sabesiensis, Special Issue, 2014. pp. 15-30.

Karabulatova, I.S., Fedorova E.A. \& Sayfulina F.S. 2014. A Linguo-Mythological Space of the Toponym "Siberia" in Contemporary Slavonic Linguistic Consciousness// World Applied Sciences Journal 30 (9). pp. 1134-1138.

Karabulatova, I.S. \& Sayfulina F.S. 2015. Mytholinguistic Interpretation of Sacral Toponym Astana in Sociocultural Practice of the Siberian Tatars. In the: Asian Social Science, Vol.11, No.5.

Yusupov, F.Yu. \& Karabulatova I.S. 2014. Some results of the research system-synchronous modern dialect of the Tatar language. In the: Life Science Journal 2014; 11 (7s). pp. 246-250.

Sayfulina, F.S., Karabulatova I.S., Yusupov F.Yus. \& Gumerov I.G. 2013. Contemporary issues of textual analysis of Turkic-Tatar literary monuments of Western Siberia. In the: World Applied Sciences Journal Issue 27 (Education, law, economics, language and communication). pp. 492-496.

Sayfulina, F.S. \& Karabultova I.S. 2014. European studies of Barabin Tatar folklore: the role of investigation of the German Scientist V.V.Radlov. In the: Life Science Journal, 2014, \# 9 (11s). pp. 116-119.

Sells, B. 2000. Working with Images (Classics in Archetypal Psychology). Book 4. pp. 207.

Zamaletdinov, R.R., Yusupov F.Yu., Karabulatova I.S., A.F. Yusupov \& Husnutdinov D.H 2014. The formation of Tatar Ethnic groups in the Southern Urals and Trans Ural region. In the: Life Science Journal. 11(11s): 214-217.

Yakhin, F.Z. 2006. The Ideas of Sufism in the works of the Ikany Sheikh. The education and culture as the factor of region's development: material of all-russian Mendeleev readings dedicated to the 90th anniversary of Tobolsk State pedagogical Institute named D.I. Mendeleyev. pp. 189. 
ISSN 2039-2117 (online) ISSN 2039-9340 (print)
Mediterranean Journal of Social Sciences MCSER Publishing, Rome-Italy
Vol 6 No 3 S4 May 2015 